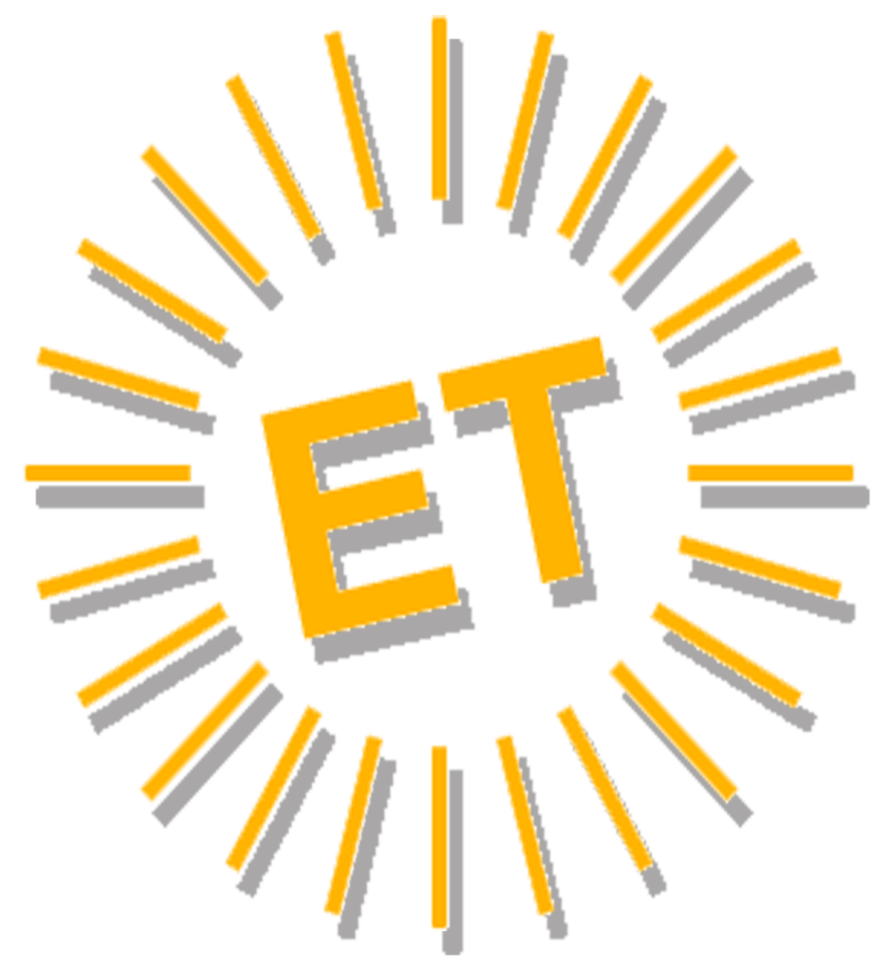




\section{Editorial Team}

\section{Editor in Chief}

Alfonso Vargas-Sánchez, University of Huelva, Spain

\section{Associate Editor}

Mirko Perano, Reald University College, Albania

\section{Books Review Editor}

Brendan Paddison, York St. John University, United Kingdom

\section{Secretariat}

Elena García de Soto, University of Huelva, Spain

Cinta Borrero-Domínguez, University of Seville, Spain

\section{Style reviewer and text editor}

Anestis Fotiadis, Zayed University, United Arab Emirates

\section{Editorial Board}

José Manuel Alcaraz, Murdoch University, Australia Mario Castellanos-Verdugo, University of Seville, Spain José Antonio Fraiz-Brea, University of Vigo, Spain José Manuel Hernández-Mogollón, University of Extremadura, Spain

Tzung-Chen Huan, National Chiayi University, Taiwan, Province of China

Shaul Krakover, Ben Gurion University, Israel Jean Pierre Levy-Mangin, University of Quebec, Canada Tomás López-Guzmán, University of Córdoba, Spain Yasuo Ohe, Chiba University, Japón

María de los Ángeles Plaza-Mejía, University of Huelva, Spain Nuria Porras-Bueno, University of Huelva, Spain João Albino Silva, Algarve University, Portugal

\section{Advisory Board (Spanish Members)}

Juan Manuel Berbel-Pineda, Pablo de Olavide University, Spain César Camisón-Zornoza, Uniersity of Valencia, Spain Enrique Claver-Cortés, University of Alicante, Spain María Teresa Fernández-Alles, University of Cádiz, Spain José Luis Galán-González, University of Seville, Spain Félix Grande-Torraleja, University of Jaén, Spain

Antonio Leal-Millán, University of Seville, Spain Inmaculada Martín-Rojo, University of Málaga, Spain Antonio Manuel Martínez-López, University of Huelva, Spain Francisco José Martínez-López, University of Huelva, Spain Pablo A. Muñoz-Gallego, University of Salamanca, Spain
Francisco Riquel-Ligero, University of Huelva, Spain José Miguel Rodríguez-Antón, Autonomous University of Madrid, Spain

Sandra Sanchez-Cañizares, University of Cordoba, Spain Josep Francesc Valls-Giménez, ESADE, Spain

\section{Advisory Board (Other European Members)}

Tindara Abbate, University of Messina, Italy Paulo Aguas, University of Algarve, Portugal Carlos Costa, Aveiro University, Portugal Dianne Dredge, Aalborg University, Denmark Salvatore Esposito de Falco, University of Rome "La Sapienza", Italy

Sheila Flanagan, Dublín Institute of Technology, Ireland Tania Gorcheva, Tsenov Academy of Economics, Bulgaria Tadeja Jere Jakulin, University of Primorska, Slovenia Metin Kozak, Mugla University, Turkey Álvaro Matias, Lusiada University, Portugal Alfonso Morvillo, National Research Council, Italy Alexandru Nedelea, Stefan cel Mare University of Suceava, Romania Claudio Nigro, University of Foggia, Italy Angelo Presenza, University "G. D'Annunzio" of Chieti-Pescara, Italy

Kanes Rajah, Royal Agricultural University, United Kingdom

\section{Advisory Board (Members from the rest of the world)}

John Allee, American University of Sharjah, United Arab Emirates

Nestor Pedro Braidot, National University of La Plata, Argentina

Roberto Elias Canese, Columbia University, Rector, Paraguay

Luca Casali, Queensland University of Technology, Australia Nimit Chowdhary, Indian Institute of Tourism and Travel Management, India

Steven Chung-chi Wu, National Pingtung University of Science and Technology, Taiwán

Dianne Dredge, Southern Cross University, Australia Daniel Fesenmaier, Temple University, United States

Babu George, Alaska Pacific University, United States Dogan Gursoy, Washington State University, United States Jafar Jafari, University of Wisconsin-Stout, United States Sanggun Lee, Pai Chai University, Korea Republic of Albert Yeh Shangpao, I-SHOU University, Taiwán Pauline Sheldon, University of Hawaii, United States Germán A. Sierra-Anaya, University of Cartagena de Indias, Rector, Colombia Xiaohua Yang, University of San Francisco, United States 
Enlightening Tourism.

A Pathmaking Journal

\title{
AN APPROACH TO CULTURAL TOURISTS' SEGMENTATION IN POST-UNESCO COIMBRA
}

\author{
Vivina Carreira \\ Polytechnic of Coimbra (Portugal) / University of Seville (Spain) \\ vivina@esac.pt
}

M. Rosario González-Rodríguez

University of Seville (Spain)

rosaglez@us.es

M. Carmen Díaz-Fernández

University of Seville (Spain)

cardiaz@us.es

\author{
José Alberto Moutela \\ University of Santiago de Compostela (Spain) \\ josealberto.tavares@rai.usc.es
}

\begin{abstract}
This paper falls within the scope of cultural tourism studies, focusing on a World Heritage Site and intends to contribute to tourism literature by trying to better understand the differences between the tourists visiting it. $A$ survey was conducted by self-administered questionnaires designed to identify different types of cultural tourists in post-UNESCO Coimbra (Portugal) so as to understand what they look for, the importance they assign to motivational factors, whether they are interested in participatory activities which call for cognitive, intellectual or affective engagement and
\end{abstract}


their degree of satisfaction. A hierarchical cluster analysis was carried out based on age, education, family income, nationality, and length of stay. To perform this analysis of identification of homogeneous groups, Ward's method and the Squared Euclidean distance were used as a measure of similarity. The variables were standardized to avoid bias due to the different scales. The results of this analysis allowed the identification of two groups. Chi-square analyses and Mann-Whitney $U$ tests were also carried out for better characterizing the clusters. Results seem to be useful for destination managers to provide what tourists seek, to enhance their experiences and satisfaction, and strengthen this destination competitiveness and value creation.

KEYWORDS

Cultural Tourism; Cultural Tourists; Segmentation; World Heritage Sites;

Coimbra

EKONLIT KEYS

Z32; Z38; Z39

\section{INTRODUCTION}

The University of Coimbra, Alta and Sofia became a World Heritage Site (WHS) in 2013 and since then this tourist destination has undergone remarkable changes which pose difficult management challenges. An empirical research was conducted aiming at better understanding the characteristics, attitudes, and perceptions of cultural tourists about Coimbra, as the designation itself may impact visitors' perception of the site and their on-site experiences. (Poria, Reichel \& Cohen, 2013)

Literature review focused on existent typologies of cultural tourists and studies based on tourism market segmentation. An empirical research used a survey which took place between June 2018 and September 2019, with a total of 582 validated questionnaires from a simple random sampling to ascertain what are cultural tourists looking for in post-UNESCO Coimbra.

Although it can be very difficult to put cultural tourists into groups or typologies as consumers, it is important to understand the way they make decisions and engage in tourism activities - it is important to the management of tourism and for the marketing of tourism products and services (Heitman, 2011: 31). Moreover, to identify what cultural tourists look for in post-UNESCO Coimbra, through a segmentation study highlighting the main characteristics, consumption motivations and cultural practices of visitors, allows for the enhancement of their experiences and satisfaction, and thereby strengthen this destination competitiveness and value creation. 


\section{THEORETICAL FRAMEWORK}

\section{1) CULTURAL TOURISM}

The World Tourism Organization (WTO, 1985: 2) defines tourism as trips that "satisfy the human need for diversity, leading to raise the cultural level of the individuals and give rise to new knowledge, experience, and encounters" supporting the idea that all tourist trips may be considered cultural.

Some authors use the expression "heritage tourism" (Chhabra, Healy \& Sills, 2003) and others, for example, Timothy (2011: 5) argue that no significant difference can be identified between cultural tourism and heritage tourism characteristics, since "consuming living and built culture in rural or urban contexts and their own personal experiences, including education and cultural edification, are an important part of the heritage tourism experience". In full agreement with Timothy's point of view, this study considers heritage tourists as cultural tourists.

As a social practice cultural tourism can be considered to foster encounters between cultural systems, which will produce mutual changes. Europe is the world's top tourist destination due to its cultural and historical heritage, natural assets, diversity of sceneries and landscapes, high quality services and good accessibility. Cultural tourism has been a very attractive and disputed economic market since it is a highspending type of tourism, practiced by highly qualified people who stimulate various types of activities in the visited areas. Stakeholders involved in this tourist activity generate a lot of income providing subsequently a high job creation rate.

Local populations welcome the results of cultural tourism, among which we can highlight examples such as boosting local incomes and subsidies for local cultural organizations. The increase of cultural tourism demand has generated the development of several new cultural attractions and cultural tourism marketing strategies, as there is fierce competition among countries and regions.

To acknowledge the concept of cultural tourism is to recognize at the same time the role of tourism as a process that involves a set of behavior practices that societies develop as well as learning and transmitting meanings that are embodied in objects or traditional cultural activities. The beginning of cultural tourism as a social phenomenon 
and an object of academic study can be traced back to the boom of post-World War 2 leisure travel. (Richards, 2018:12)

As mentioned above, the definition of "cultural tourism" is neither easy nor consensual, with more than one approach - from the perspective which considers that all forms of tourism involve cultural practices and experiences to more restrictive ones. Several entities have presented definitions of "cultural tourism", from the International Council for Monuments and Sites (ICOMOS), to the World Tourism Organization (WTO) (now United Nations World Tourism Organization - UNWTO), the International Coalition of Tourism Partners (ICTP), the Association for Tourism and Leisure Education (ATLAS), Universities, and researchers and all of these definitions have, over time, broadened the scope of what is considered cultural tourism.

Many definitions have also been advanced by scholars over the years of cultural tourism and cultural tourists (inter alia Richards, 1996; Du Cros \& McKercher, 2014 and Barbieri \& Mahoney, 2010) but cultural tourism has been the object of a new definition from the UNWTO at the $22^{\text {nd }}$ Session of the General Assembly held in Chendu, China, which considerably broadens the scope of cultural tourism and, in full agreement with the UNWTO Report (2018), the emphasis is shifting from the classic demand for monuments and sites to a broader range of cultural practices and lifestyles. According to that definition,

Cultural tourism is a type of tourism activity in which the visitor's essential motivation is to learn, discover, experience and consume the tangible and intangible cultural attractions/products in a tourism destination. These attractions/products relate to a set of distinctive material, intellectual, spiritual and emotional features of a society that encompasses arts and architecture, historical and cultural heritage, culinary heritage, literature, music, creative industries and the living cultures with their lifestyles, value systems, beliefs and traditions. (UNWTO, 2017: 18)

To define cultural tourism, it is paramount to focus on the motivations of demand. Culture, seen from a comprehensive and holistic perspective, embodied in a set of symbols, namely in architecture and art, among others, and manifested in language, folklore and in daily life, sustains the diversity of motivations behind these trips whose 
interest lies, among others, in values, symbols and meanings of the material and intangible assets of the communities. Interest in cultural tourism has been growing and a few segments have emerged such as arts tourism, film tourism, gastronomic tourism, religious tourism, literary tourism.

A new trend, the 'creative turn' in cultural tourism, is "driving a shift towards less tangible tourism assets and more actively involved forms of tourism consumption" (Richards \& Marques, 2012), opening up a growing range of cultural tourism niches related to specific aspects or dimensions of culture that destinations are developing (Novelli \& Benson, 2005; Richards \& Raymond, 2000; Richards, 2018; Quinteiro, Carreira \& Gonçalves, 2020; Carreira, Azeredo, González-Rodriguez \& DíazFernández, 2021).

\section{2) THE DOUBLE-EDGED SWORD OF THE UNESCO SEAL - MOTIVATION AND IMPACTS}

Some author experts are skeptical about the changes that can be witnessed nowadays wherein the noble original principles underlying the UNESCO idea for safeguarding and preserving humanity heritage may have become of secondary importance as political and economic interests are overwhelming (Meskell, 2014: 236237; Frey, Pamini \& Steiner, 2013) and that an objective re-evaluation of the UNESCO 1972 Convention is overdue (Cleere, 2011; Meskell, 2012, 2014). "For local and regional politicians, heritage thus turns into a tricky arena indeed. It is hard to clearly separate cultural historical, economic, ecological and aesthetic arguments." (Bendix, 2009: 262)

Being on the UNESCO list is highly desirable by many sites as it brings prominence and monetary revenue (Santa-Cruz \& López-Guzmán, 2017) to increase communities' income and also take part in conservation costs (Jimura, 2019); besides, it also raises interest in WHS-related issues of identity and sustainability (Landorf, 2009; Bourdeau, Gravari-Barbas \& Robinson, 2016). It is an attractive brand for cultural tourism and a guarantee of quality and singularity. Giving an image of prestige at international and national levels, it can also influence decisions on local planning (Smith, 2002). A renewal of interest of residents in their town and people's pride on their culture have been identified. (Evans, 2002; Jimura, 2011) 
Nevertheless, WHS listing almost always results in increasing tourist influx, with heavy impacts (Yang, Lin \& Han, 2010; Kim, 2016; Silva \& Carvalho, 2017) having to be faced in managing $\mathrm{WH}$ cultural sites regarding organization structures, the mitigation of pressure, overload and threats (Seraphin, Sheeran \& Pilato, 2018; Carreira et al., 2021; Quinteiro et al., 2020) through programs and strategies or policies to generate sustainable economic and social impacts for the residents in and around WHS in the way of a proper balance between conservation, sustainability, development and creation of value. Timothy \& Boyd (2003: 281) state that "the significance and value that lie within heritage is not in how it is defined, but in how it is used to create meaningful experiences for tourists"; an overloaded site, threatened in the qualities that precisely make it distinctive, can hardly provide good and memorable experiences.

Segmentation is, then, a tool for managing demand and provide sustainable tourism development. Comprehending motivations is key to understanding tourists' decisions and behaviors (Iso-Ahola, 1982; Kolar \& Zabkar, 2010; Ribeiro, Vareiro \& Santos, 2014; Ramires, Brandão \& Sousa, 2018). Taheri, Jafari \& O'Gorman (2014) argue that better engagement with an attraction and its contents enhances the overall tourist experience and concomitantly it valorizes the attraction itself.

The authors found three main drivers of visitor engagement: prior knowledge, multiple motivations, and cultural capital. Poria, Reichel \& Biran (2006) examine the relationship between tourists and the heritage visited and identify three categories of heritage visit motives: the desire to feel connected to the history presented, the desire to learn, and motives not linked to the historical attributes of the site, such as tourists' perception of heritage settings as part of their own heritage (Poria, Butler \& Airey, 2001). Timothy (1997: 1) spoke of personal experience - millions travel for the purpose of experiencing a "heritage of a more personal nature", to feel connected to ancestors (Bryce, Curran, O'Gorman \& Taheri, 2015) and nostalgia (Chhabra et al, 2003). Richards mentions search for knowledge and learning from the past and engage in active creative activities, of which he highlights intellectual creativity. (Richards, 2011: 1239)

Many scholars have addressed the issue of heritage management whose big challenge is perhaps to achieve a balance point of sustainability by managing tourists in a way that enhances the quality of their experiences and at the same time preserves 
heritage properties and resources for the future (Alazaizeh, Halo, Backman, Norman \& Vogel, 2016; Mckercher, Ho \& du Cros, 2005). According to Alazaized et al. (2016) one group of stakeholders is being ignored: the tourists. They argue that to achieve sustainability in heritage tourism it is essential to involve and understand value orientations of different stakeholders including tourists in decision-making; therefore, this study tries to fill-in this gap in literature.

\subsection{1) CULTURAL TOURISTS IN POST-UNESCO COIMBRA}

It is important to collect information through scientific studies to analyze and characterize in general the demand of a tourist destination. Understanding tourist behavior and cultural identity and diversity were given highest importance by experts responding on cultural tourism development and culture partnership (UNWTO, 2018: 60):

Understanding tourist behavior was seen as most important specific policy area, followed by diversification and then balancing promotion and protection of culture. Those countries that prioritize product development and marketing also rank understanding tourist behavior and diversification highly. For the experts the development of integrated approaches to tourism and culture and community empowerment and inclusion were seen as the main policy priorities. (UNWTO, 2018: 94-95)

Many authors have come to differentiate between cultural tourists categories that place them in the spectrum of coming to culture more by accident, a complementary activity or an activity specifically sought after or desired (inter alia, McKercher \& du Cros, 2002, McKercher et al., 2005; Richards \& Wilson, 2007; Richards \& van der Ark, 2013; Nguyen \& Cheung, 2014). Heitman (2011: 33-37) summarizes some of the attempts that scholars have done in proposing tourists' roles and typologies, from Gray's to Plog's to Cohen's and Smith's and has identified overlaps between the different theories, particularly if a spectrum familiarity - novelty is used. Moreover, he has concluded that, despite these theories' usefulness, in knowing tourists' characteristics and personal traits for identifying market segments and develop 
adequate products and services, they are rather simplistic as they don't tell us anything about the underlying reasons differentiating types (p. 36).

The most prevailing typology of cultural tourists is probably the one advanced by McKercher (2002) which categorizes cultural tourists according to their depth of experience as well as the importance of culture, as a motivator, in their travel. The first three types of cultural tourists - the purposeful, the sightseeing and the serendipitous types - can, arguably, be considered as the primary cultural tourists due to their main motivator and experience for choosing a destination for the sake of cultural values. These three can be considered as specialized and the other two - casual and incidental types - are within the category of general cultural tourists.

The spectrum of cultural tourists is very wide ranging from recreational tourists who happen to participate in some cultural tourism activity to enhance their experience to those who explicitly travel in search of cultural tourism activities (McKercher \& du Cros, 2003).

This model considers two dimensions: centrality of cultural tourism in the decision to visit a destination and the depth of experience. When segmenting the cultural tourism market, the level of engagement is important and depends on several factors: different abilities to engage due to level of education, awareness of the site previous to the visit, preconceptions on the site, interest in the site, its meaning to them, time availability, the presence or absence of competing activities (McKercher, 2002).This model has recently been questioned and the typology reduced, due to the argument that a much more balanced segmentation of cultural tourists can be reached "after eliminating the determination effect of cultural centrality on depth of cultural experience" (Chen \& Huang, 2017: 253).

Most past and recent research (Santa-Cruz \& López-Guzmán, 2017; LópezGuzmán, Pérez Gálvez, Muñoz-Fern \& Medina-Viruel, 2018; Ramires et al., 2018) on cultural tourists' typologies have categorized cultural tourists on a continuum of different factors ranging from cultural interest, motivation and engagement in cultural activities and coming up with different numbers of clusters. All the typologies proposed coincide in characteristics that allow for the consideration of two large groups: i) Tourists who consume culture because itis their main motivation and ii) Those for whom culture is only a complement or secondary or even accidental element. 
The present research intends to identify some characteristics of tourists visiting Coimbra after the UNESCO listing, to understand the types of cultural tourists, their motivations, behaviors, perceptions, experiences that in turn will help in designing management strategies having as main priority the protection and conservation of the heritage features that make the site unique (Zhu, 2012; Uriely, 2005; Cutler \& Carmichael, 2010; Tiberghien, Bremner \& Milnec, 2017).

\section{METHOD, SAMPLE AND DATA}

\section{1) STUDY SITE AND CONTEXT}

Coimbra, in Central Portugal, is the seat of one of the oldest universities in Europe whose history goes back to the $13^{\text {th }}$ Century. In June 2013 , Coimbra saw the University of Coimbra - Alta and Sofia inscribed on the UNESCO World Heritage list, an ensemble composed of many medieval colleges, cathedrals, churches, museums, a baroque library, modern buildings, and a Botanical Garden. In July 2019, the Machado de Castro National Museum was integrated into this classified group. This classification was due both to its material heritage, given the exceptional nature of its architectural features, and for its intangible legacy, notably for the role it played in the dissemination of the Portuguese language and culture. Its global significance is noticeable in the growing number of visitors in recent years, which also poses critical challenges to cultural tourism managers.

According to the National Statistical Institute, Coimbra received 202,490 tourists in 2013, year of the UNESCO classification. The University ensemble registered an increase of $31 \%$ in visits from 2012 to 2013 (Menezes, 2017). From data provided by the University of Coimbra, in 2016 the University welcomed 450,000 tourists, which represents an increase of $26 \%$ comparing to the figures in 2015 . The University registered 538,000 visitors in 2017 and 581,040 visitors in 2018, of which 54\% came from Portugal and $46 \%$ from other countries.

\section{2) DATA COLLECTION}


Surveys by questionnaire (Smith, 2017) are an important tool for gathering information, since it is about involving people in the collection of a multiplicity of elements - opinions, attitudes, perceptions, experiences, and behavior. The development and implementation of this tool improves the quality of the research with an original matrix of information. In the field of tourism research, the questionnaire survey technique is one of the most used. (Chi \& Qu, 2008; Smith, 2017, Veal, 2017)

The questionnaire was designed with a wide panel of variables intended to assess the knowledge of tourists about the city, the image of the tourist destination of Coimbra, as a WHS, regarding motivations and tourists' satisfaction, as well as assess the most sought-after elements in the sites and the kind of activities they preferred to engage themselves in.

Questionnaires were administered between June 2018 and September 2019, every day of the week, even on weekends, at different hours of the day, for more than one year, at different monuments of the city. We used a simple random sampling to collect the data and from information provided by the University of Coimbra about visitors' profiles in Coimbra, we chose a representative sample across different ages, gender, and nationalities. The final sample consisted of 582 validated questionnaires.

The empirical research displayed here is part of a broader research project on the areas classified by UNESCO in the city of Coimbra. In the present study, the analysis focuses on the profiles of visitors. The article also aims to identify homogeneous groups of tourists who visit the city of Coimbra according to their distinct characteristics and activities carried out during the trip. Data were collected in the several buildings and areas of the UNESCO-classified parts of the city of Coimbra as well as in accommodation units. The interviewees were asked to collaborate, filling-in the questionnaire according to their interests and opinions.

Respondents were also asked to provide information about: i) the number of visits and places visited in the city of Coimbra; ii) the way they found out about the city of Coimbra and their degree of knowledge about a set of items, such as the history of the city, the University, students' traditions, Coimbra Fado (a different version of the national song), museums and parks; and iii) their socioeconomic profile.

\section{3) DESCRIPTION OF SAMPLE}


Segmentation and identification of targeted publics is a fundamental analysis tool, namely in the analysis and marketing approach of a tourist destination. In this sense, the concept of segmentation has been presented as a process of dividing a market into homogeneous subsets of people, travelers, or tourists. An analysis of these subgroups allows the definition, design and promotion of strategies aimed at meeting the identified needs of the target groups (Loker \& Perdue, 1992). Moreover, according to these authors, an efficient market segmentation research can provide relevant and valuable operational information for direct use in the design of strategies.

When defining a segmentation base, sociodemographic characteristics, such as age, family income, academic training and nationality, are pointed out as frequent variables, as being the most useful due to the ease of their collection and evaluation (Lawson, 1995; Kastenholz, 2004), in addition to others related to tourist behavior.

In the context of cultural tourism, the educational level of the tourist can be considered particularly relevant, but differences in age may also have different impacts on tourist behavior; the level of family income also seems to be an important determinant in the consumption pattern in the context of cultural tourism. (Kastenholz, Carneiro \& Eusébio, 2005)

To evaluate respondents' answers, a 7-point Likert scale was used, where 1 corresponds "I completely disagree"/"Not important at all"/ or "Not satisfied at all"; 2, "I disagree"/"Not very important" or "Not satisfied"; 3, "I disagree to some extent"/"Important to some extent" or "Satisfied to some extent"; 4, "Neither agree nor disagree"/ "Quite important" or "Quite satisfied"; 5, "I agree to some extent"/ "Important" or "Satisfied"; 6, "I agree"/"Important" or "Satisfied"; and 7, "I totally agree"|"Very important" or "Very satisfied".

To select the sample, a random approach was used, casually inviting tourists who were on the places mentioned above to participate in the survey. For data analysis, version 23 of the SPSS statistical application was used. 


\begin{tabular}{|c|c|c|c|}
\hline Variables & Description & $\mathrm{N}$ & $\%$ \\
\hline \multirow{3}{*}{ Gender } & Male & 284 & $48,8 \%$ \\
\hline & Female & 298 & $51,2 \%$ \\
\hline & Total & 582 & $100,0 \%$ \\
\hline \multirow{6}{*}{ Age } & Less than 19 years old & 84 & $14,4 \%$ \\
\hline & Between 20 and 34 years & 224 & $38,5 \%$ \\
\hline & Between 35 and 49 years & 141 & $24,2 \%$ \\
\hline & Between 50 and 64 years & 87 & $14,9 \%$ \\
\hline & More then 65 years old & 46 & $7,9 \%$ \\
\hline & Total & 582 & $100,0 \%$ \\
\hline \multirow{4}{*}{$\begin{array}{l}\text { Level of } \\
\text { education }\end{array}$} & Basic education & 10 & $1,7 \%$ \\
\hline & Secondary education & 204 & $35,2 \%$ \\
\hline & Higher education & 366 & $63,1 \%$ \\
\hline & Total & 580 & $100,0 \%$ \\
\hline \multirow{5}{*}{$\begin{array}{l}\text { Net monthly } \\
\text { household } \\
\text { income }\end{array}$} & Up to $1.500 €$ & 168 & $29,0 \%$ \\
\hline & From $1.501 €$ to $3.000 €$ & 197 & $34,0 \%$ \\
\hline & From $3.001 €$ to $5.000 €$ & 170 & $29,4 \%$ \\
\hline & More than $5.001 €$ & 44 & $7,6 \%$ \\
\hline & Total & 579 & $100,0 \%$ \\
\hline \multirow{3}{*}{ Nationality } & Portuguese & 268 & $46,0 \%$ \\
\hline & Foreigner & 314 & $54,0 \%$ \\
\hline & Total & 582 & $100,0 \%$ \\
\hline
\end{tabular}

\begin{tabular}{|c|c|c|c|}
\hline Variables & Description & $\mathrm{N}$ & $\%$ \\
\hline \multirow{9}{*}{$\begin{array}{l}\text { Economic } \\
\text { status / } \\
\text { Sector of } \\
\text { professional } \\
\text { activity }\end{array}$} & Agriculture, handicrafts, fishing & 34 & $5,9 \%$ \\
\hline & Industry & 87 & $15,1 \%$ \\
\hline & Trade, hotels and restaurants & 115 & $20,0 \%$ \\
\hline & Public sector and services & 178 & $30,9 \%$ \\
\hline & Retired & 38 & $6,6 \%$ \\
\hline & Student & 109 & $18,9 \%$ \\
\hline & Unemployed & 6 & $1,0 \%$ \\
\hline & Other & 9 & $1,6 \%$ \\
\hline & Total & 576 & $100,0 \%$ \\
\hline \multirow{3}{*}{$\begin{array}{l}\text { First time in } \\
\text { Coimbra? }\end{array}$} & No & 239 & $41,1 \%$ \\
\hline & Yes & 343 & $58.9 \%$ \\
\hline & Total & 582 & $100,0 \%$ \\
\hline \multirow{3}{*}{$\begin{array}{l}\text { Hosted in } \\
\text { Coimbra? }\end{array}$} & No & 88 & $15,2 \%$ \\
\hline & Yes & 492 & $84,4 \%$ \\
\hline & Total & 580 & $100,0 \%$ \\
\hline \multirow{7}{*}{$\begin{array}{c}\text { Main reason / } \\
\text { motivation to } \\
\text { stay in } \\
\text { Coimbra }\end{array}$} & Leisure and vacation & 184 & $31,7 \%$ \\
\hline & Rest and health reasons & 10 & $1,7 \%$ \\
\hline & Visit UNESCO World Heritage & 195 & $33,6 \%$ \\
\hline & Cultural and recreational events & 84 & $14,5 \%$ \\
\hline & Visit friends or relatives & 43 & $7,4 \%$ \\
\hline & Other & 64 & $11,0 \%$ \\
\hline & Total & 580 & $100,0 \%$ \\
\hline
\end{tabular}

Table 1. Sociodemographic and economic profile of the sample of tourists and visitors Source: questionnaires administered by the authors

The sample comprises a relatively balanced distribution between men $(48.8 \%, \mathrm{n}=$ 284 ) and women $(51.2 \%, n=298)$; there is a greater concentration of respondents in the middle age groups, with $38.5 \%$ of respondents aged 20 to 34 years $(n=224)$ and $24.2 \%$ in the age group 35-49 years $(n=141)$. Most respondents had higher/college education $(63.1 \%, n=366)$. As far as average monthly family income, $34.0 \%(n=197)$ declared to receive from $€ 1,500$ to $€ 3,000$ and $29.4 \%(n=170)$ from $€ 3,001$ to $€$ 5,000 . A majority of $54 \%(n=314)$ were foreign tourists against $46 \%(n=268)$ of national tourists. Likewise, a majority of tourists were visiting Coimbra for the first time $(58.9 \%, n=343)$ and were also hosts in accommodation units $(84.8 \%, n=492)$. The sample also shows that $33.6 \%(n=195)$ of the respondents visited the city because it is a UNESCO World Heritage Site, and $31.7 \%(n=184)$ did it for vacation and leisure.

\section{RESULTS AND DISCUSSION}

A hierarchical cluster analysis was carried out based on age, education, family income, nationality, and length of stay. To perform this analysis of identification of homogeneous groups, Ward's method and the Squared Euclidean distance were used as a measure of similarity. The variables were standardized to avoid bias due to the different scales. The results of this analysis allowed the identification of two groups. 
Chi-square analyses and Mann-Whitney $U$ tests were also carried out for better characterizing the clusters and identifying the main differences between them (Tables 2 and 3$)$.

Cluster 1 is composed of tourists and visitors of younger ages, mostly students, with a higher level of education and a lower economic level, they are mostly Portuguese and have already been to Coimbra several times. On the other hand, cluster 2 is formed by people of older age groups, also with higher education, who tend to work in the services and industry sectors, have a higher level of economic income, are mostly foreigners and travelling to Coimbra for the first time.

\begin{tabular}{|c|c|c|c|c|c|c|}
\hline Variables & Description & $\begin{array}{c}\text { Cluster } 1 \\
\mathrm{~N}=255 \\
(44,8 \% \text { of } \\
\text { respondents) }\end{array}$ & $\begin{array}{c}\text { Cluster } 2 \\
\mathrm{~N}=314 \\
\text { (55,2\% of } \\
\text { respondents) }\end{array}$ & $\begin{array}{c}\text { Level of } \\
\text { significance } \\
p\end{array}$ & Chi-square & d.f. \\
\hline \multirow{2}{*}{ Gender } & Male & 51,4 & 47,1 & \multirow{2}{*}{0,314} & \multirow{2}{*}{1,012} & \multirow{2}{*}{1} \\
\hline & Female & 48,6 & 52,9 & & & \\
\hline \multirow{5}{*}{ Age } & Less than 19 years old & 30,2 & 1,9 & \multirow{5}{*}{0,000} & \multirow{5}{*}{259,493} & \multirow{5}{*}{4} \\
\hline & Between 20 and 34 years & 58,8 & 21,7 & & & \\
\hline & Between 35 and 49 years & 8,2 & 37,3 & & & \\
\hline & Between 50 and 64 years & 0,8 & 26,8 & & & \\
\hline & More then 65 years old & 2,0 & 12,4 & & & \\
\hline \multirow{3}{*}{$\begin{array}{l}\text { Level of } \\
\text { education }\end{array}$} & Basic education & 2,4 & 1,0 & \multirow{3}{*}{0,000} & \multirow{3}{*}{5,522} & \multirow{3}{*}{2} \\
\hline & Secondary education & 30,6 & 38,9 & & & \\
\hline & Higher education & 67,1 & 60,2 & & & \\
\hline \multirow{8}{*}{$\begin{array}{c}\text { Economic } \\
\text { status / Sector } \\
\text { of professional } \\
\text { activity }\end{array}$} & Agriculture, handicrafts, fishing & 0,0 & 10,8 & \multirow{8}{*}{0,000} & \multirow{8}{*}{224,772} & \multirow{8}{*}{7} \\
\hline & Industry & 4,7 & 23,6 & & & \\
\hline & Trade, hotels and restaurants & 16,1 & 22,9 & & & \\
\hline & Public sector and services & 29,8 & 32,2 & & & \\
\hline & Retired & 2,0 & 10,2 & & & \\
\hline & Student & 42,0 & 0,3 & & & \\
\hline & Unemployed & 2,0 & 0,0 & & & \\
\hline & Other & 3,5 & 0,0 & & & \\
\hline \multirow{4}{*}{$\begin{array}{l}\text { Net monthly } \\
\text { household } \\
\text { income }\end{array}$} & Up to $1.500 €$ & 54,5 & 8,3 & \multirow{4}{*}{0,000} & \multirow{4}{*}{202,540} & \multirow{4}{*}{3} \\
\hline & From $1.501 €$ to $3.000 €$ & 36,5 & 32,2 & & & \\
\hline & From $3.001 €$ to $5.000 €$ & 6,3 & 48,4 & & & \\
\hline & More than $5.001 €$ & 2,7 & 11,1 & & & \\
\hline \multirow{2}{*}{ Nationality } & Portuguese & 70,2 & 26,8 & \multirow{2}{*}{0,000} & \multirow{2}{*}{106,850} & \multirow{2}{*}{1} \\
\hline & Foreigner & 29,8 & 73,2 & & & \\
\hline \multirow{2}{*}{$\begin{array}{l}\text { First time in } \\
\text { Coimbra? }\end{array}$} & No & 61,6 & 24,5 & \multirow{2}{*}{0,000} & \multirow{2}{*}{79,765} & \multirow{2}{*}{1} \\
\hline & Yes & 38,4 & 75,5 & & & \\
\hline \multirow{2}{*}{$\begin{array}{l}\text { Hosted in } \\
\text { Coimbra? }\end{array}$} & No & 14,1 & 16,6 & \multirow{2}{*}{0,423} & \multirow{2}{*}{0,642} & 1 \\
\hline & Yes & 85,9 & 83,4 & & & 1 \\
\hline
\end{tabular}

Table 2. Differences between the two groups of cultural tourists surveyed in Coimbra - socioeconomic characteristics

Source: questionnaires administered by the authors

These segments were subsequently analyzed in relation to other aspects of the sociodemographic profile and travel decisions and exhibited significant differences. 
The results from the analysis of the clusters reveal that in cluster 1 there is a prevalence of students, with a high level of education and a lower level of average monthly income. It seems that this can be explained to a certain extent by the fact that Coimbra is known as the "city of knowledge and the city of students", constituting a pole of attraction for young people from all over the country. On the other hand, cluster 2 shows a greater concentration of individuals in the older age groups, who are more professionally active, exhibit a higher level of wealth and travel to Coimbra for the first time.

\begin{tabular}{|c|c|c|c|c|c|c|}
\hline Variables & Description & $\begin{array}{c}\text { Cluster } 1 \\
\mathrm{~N}=255 \\
(44,8 \% \text { of } \\
\text { respondents) }\end{array}$ & $\begin{array}{c}\text { Cluster } 2 \\
N=314 \\
\text { (55,2\% of } \\
\text { respondents) }\end{array}$ & $\begin{array}{c}\text { Level of } \\
\text { significance } \\
p\end{array}$ & Chi-square & d.f. \\
\hline \multirow{8}{*}{$\begin{array}{l}\text { Accommodation } \\
\text { modality }\end{array}$} & Hotel & 20,1 & 54,2 & \multirow{8}{*}{0,000} & \multirow{8}{*}{123,957} & \multirow{8}{*}{7} \\
\hline & Hostel & 11,9 & 8,0 & & & \\
\hline & Rural Tourism & 9,1 & 8,8 & & & \\
\hline & Guest house & 3,2 & 14,5 & & & \\
\hline & Camping & 0,9 & 0,4 & & & \\
\hline & Friends house & 11,9 & 7,3 & & & \\
\hline & Owned house & 32,9 & 5,0 & & & \\
\hline & Rented house & 10,0 & 1,9 & & & \\
\hline \multirow{4}{*}{ Length of stay } & Less than 2 days & 33,9 & 41,2 & \multirow{4}{*}{0,000} & \multirow{4}{*}{86,102} & \multirow{4}{*}{3} \\
\hline & From 2 to 5 days & 50,0 & 39,6 & & & \\
\hline & From 5 to 7 days & 8,1 & 9,2 & & & \\
\hline & More than 7 days & 8,1 & 10,0 & & & \\
\hline \multirow{3}{*}{$\begin{array}{l}\text { Image of } \\
\text { Coimbra before } \\
\text { the trip }\end{array}$} & Not good or unfavorable & 19,6 & 30,3 & \multirow{3}{*}{0,000} & \multirow{3}{*}{56,483} & \multirow{3}{*}{6} \\
\hline & Neither adverse nor favoravle & 23,1 & 39,2 & & & \\
\hline & Favorable or excelent & 57,3 & 30,6 & & & \\
\hline \multirow{6}{*}{$\begin{array}{l}\text { Main reason and } \\
\text { motivation to } \\
\text { stay in Coimbra }\end{array}$} & Leisure and vacation & 32,4 & 31,5 & \multirow{6}{*}{0,000} & \multirow{6}{*}{48,251} & \multirow{6}{*}{5} \\
\hline & Rest and health reasons & 2,0 & 1,3 & & & \\
\hline & Visit UNESCO World Heritage & 23,7 & 42,0 & & & \\
\hline & Cultural and recreational events & 12,6 & 15,9 & & & \\
\hline & Visit friends or relatives & 10,3 & 4,8 & & & \\
\hline & Other & 19,0 & 4,5 & & & \\
\hline \multirow{7}{*}{$\begin{array}{c}\text { How they came } \\
\text { to know about } \\
\text { Coimbra }\end{array}$} & Advertisement in media & 11,0 & 7,3 & \multirow{7}{*}{0,000} & \multirow{7}{*}{77,730} & \multirow{7}{*}{5} \\
\hline & Tourism flyers & 3,5 & 2,5 & & & \\
\hline & Travel agency & 9,8 & 21,0 & & & \\
\hline & Internet & 14,2 & 38,5 & & & \\
\hline & Social networks & 6,3 & 4,8 & & & \\
\hline & Friends and relatives & 30,7 & 17,2 & & & \\
\hline & Other & 24,4 & 8,6 & & & \\
\hline
\end{tabular}

Table 3. Differences between the two groups of cultural tourists surveyed in Coimbra - characteristics of the trip Source: questionnaires administered by the authors 
Regarding travelling decision making, previous image, length of stay, main motivation and source of information while respondents in cluster 1 tend to extend their stay up to 5 days, respondents in cluster 2 tend to stay overnight in hotels and be in the city for very short periods, up to 2 days. As far as the variable previous image they had of Coimbra before their visit, there also seems to be differences between the two groups; in fact, while cluster 1 concentrates on an excellent or very favorable image, respondents in cluster 2 are distributed almost evenly between images that are not at all favorable or very favorable. Cluster 1 tourists are moved more for reasons of vacation and leisure and have friends and family as their main source of knowledge; cluster 2 respondents' main motivation for visiting Coimbra is the UNESCO WHS status, and resorted to internet to getting to know the city and its heritage. 


\begin{tabular}{|c|c|c|c|c|c|c|}
\hline Variables & Description & $\begin{array}{c}\text { Cluster } 1 \\
\mathrm{~N}=255 \\
(44,8 \% \text { of } \\
\text { respondents) }\end{array}$ & $\begin{array}{c}\text { Cluster } 2 \\
\mathrm{~N}=314 \\
(55,2 \% \text { of } \\
\text { respondents) }\end{array}$ & $\begin{array}{c}\text { Level of } \\
\text { significance } \\
p\end{array}$ & $\begin{array}{c}\text { Chi- } \\
\text { square }\end{array}$ & d.f. \\
\hline \multirow{3}{*}{$\begin{array}{c}\text { Motivational importance - } \\
\text { Coimbra World Heritage } \\
\text { UNESCO }\end{array}$} & Unimportant or not important & 8,7 & 3,3 & \multirow{3}{*}{0,000} & \multirow{3}{*}{79,668} & \multirow{3}{*}{6} \\
\hline & Neither important nor unimportant & 10,7 & 2,8 & & & \\
\hline & Relevant or totally important & 80,6 & 94,0 & & & \\
\hline \multirow{3}{*}{$\begin{array}{l}\text { Motivational importance - } \\
\text { Increase historic } \\
\text { knowledge }\end{array}$} & Unimportant or not important & 5,6 & 1,9 & \multirow{3}{*}{0,000} & \multirow{3}{*}{47,538} & \multirow{3}{*}{6} \\
\hline & Neither important nor unimportant & 4,8 & 4,2 & & & \\
\hline & Relevant or totally important & 89,6 & 93,9 & & & \\
\hline \multirow{3}{*}{$\begin{array}{l}\text { Motivational importance - } \\
\text { Historic architecture and } \\
\text { preservation }\end{array}$} & Unimportant or not important & 6,4 & 3,5 & \multirow{3}{*}{0,000} & \multirow{3}{*}{55,121} & \multirow{3}{*}{6} \\
\hline & Neither important nor unimportant & 12,9 & 3,5 & & & \\
\hline & Relevant or totally important & 80,7 & 92,9 & & & \\
\hline \multirow{3}{*}{$\begin{array}{c}\text { UNESCO World Heritage } \\
\text { designation is valid to } \\
\text { Coimbra }\end{array}$} & Disagree or completely disagree & 2,4 & 1,9 & \multirow{3}{*}{0,000} & \multirow{3}{*}{28,802} & \multirow{3}{*}{5} \\
\hline & Neither agree nor disagree & 6,3 & 0,6 & & & \\
\hline & Agree or completely agree & 91,3 & 97,4 & & & \\
\hline \multirow{3}{*}{$\begin{array}{l}\text { UNESCO World Heritage } \\
\text { designation benefits local } \\
\text { economy }\end{array}$} & Disagree or completely disagree & 3,6 & 2,2 & \multirow{3}{*}{0,003} & \multirow{3}{*}{18,134} & \multirow{3}{*}{5} \\
\hline & Neither agree nor disagree & 4,8 & 9,6 & & & \\
\hline & Agree or completely agree & 91,6 & 88,2 & & & \\
\hline \multirow{3}{*}{$\begin{array}{l}\text { UNESCO World Heritage } \\
\text { promotes the development } \\
\text { of tourism }\end{array}$} & Disagree or completely disagree & 1,6 & 1,0 & \multirow{3}{*}{0,057} & \multirow{3}{*}{10,725} & \multirow{3}{*}{5} \\
\hline & Neither agree nor disagree & 4,5 & 1,6 & & & \\
\hline & Agree or completely agree & 93,9 & 97,4 & & & \\
\hline \multirow{3}{*}{$\begin{array}{c}\text { Surrounding region } \\
\text { UNESCO World Heritage - } \\
\text { Increases tourism }\end{array}$} & Disagree or completely disagree & 10,1 & 10,0 & \multirow{3}{*}{0,092} & \multirow{3}{*}{10,890} & \\
\hline & Neither agree nor disagree & 14,2 & 9,0 & & & 6 \\
\hline & Agree or completely agree & 75,7 & 81,0 & & & \\
\hline UNESCO World Heritage & Disagree or completely disagree & 8,1 & 4,2 & & & \\
\hline Coimbra - During the visit I & Neither agree nor disagree & 17,0 & 6,7 & 0,001 & 21,971 & 6 \\
\hline sensed the history & Agree or completely agree & 74,9 & 89,1 & & & \\
\hline UNESCO World Heritage & Disagree or completely disagree & 10,2 & 4,8 & & & \\
\hline Coimbra - I enjoyed a & Neither agree nor disagree & 19,9 & 7,1 & 0,000 & 31,424 & 6 \\
\hline unique experience & Agree or completely agree & 69,9 & 88,1 & & & \\
\hline & Unsatisfied or not satisfied & 3,2 & 2,9 & & & \\
\hline My overall satisfaction with & Neither satisfied nor dissatisfied & 11,6 & 4,8 & 0,031 & 13,863 & 6 \\
\hline & Satisfied or fully satisfied & 85,2 & 92,3 & & & \\
\hline & Disagree or completely disagree & 5,2 & 3,6 & & & \\
\hline The visit holiday was & Neither agree nor disagree & 17,7 & 5,5 & 0,000 & 28,898 & 6 \\
\hline & Agree or completely agree & 77,0 & 90,9 & & & \\
\hline recommend the visit to & Disagree or completely disagree & 4,3 & 2,9 & & & \\
\hline WHS Coimbra to family & Neither agree nor disagree & 5,9 & 3,2 & 0,019 & 15,160 & 6 \\
\hline and friends & Agree or completely agree & 89,8 & 93,9 & & & \\
\hline
\end{tabular}

Table 4. Differences between the two groups of cultural tourists surveyed in Coimbra - importance of motivational factors

Source: questionnaires administered by the authors

Cluster 2, composed of older tourists, assigns a greater degree of importance to the UNESCO WHS status of Coimbra, this being even their main motivating factor for visiting the city; concomitantly, they consider it very relevant for eliciting knowledge of local history. These are also the respondents who see historic architecture and its 
preservation as a motivational factor for visiting the city. However, it is cluster 1 , composed of the youngest and the students, who recognize that the UNESCO classification can bring greater economic benefits to the region; the older group doesn't show much conviction in this regard. On the other hand, both clusters tend to bring their perceptions closer as to the fact that UNESCO's classification promotes and increases the development of tourism, as well as it may extend this development to the surrounding region. Cluster 2 visitors showed greater sensitivity than cluster 1 visitors when it comes to learning about history, legends, and outstanding personalities from the Coimbra region, as well as by expressing greater appreciation for the experiences they had during their trip and stay. This tendency of cluster 2 in valuing the experiences provided by tourist activities led to a greater appreciation of their satisfaction with the visit or vacation as well as the feeling that the visit or vacation in Coimbra exceeded their initial expectations.

Despite some differences, the analysis of the results in table 4 seems to indicate that the classification of World Heritage by UNESCO has a positive impact on the motivations of tourist demand, which reflects globally on benefits and synergies on all local cultural elements. Finally, and derived from the cluster 2 travel decision making and main motivation factors already analyzed, they are the ones who have shown more loyalty to the WHS tourist destination, in recommending it to friends and family.

\section{CONCLUSION}

Cultural tourism undoubtedly constitutes an important segment of the tourism industry and has indeed generated interest among scholar and practitioners. Some studies point to specific characteristics and trends in the cultural tourism market, the emergence of some cultural tourism sub-segmentation into niches, etc. (inter alia Novelli \& Benson, 2005; Richards \& Raymond, 2000; Richards \& Wilson, 2007; Richards, 2018; Quinteiro, et al., 2020).The present study clearly highlights the existence of different cultural tourist segments within that market. The two segments identified through cluster analysis based on age, education level, income level, nationality, and length of stay in Coimbra, revealed significant differences regarding other sociodemographic and attitudinal variables associated with the trip. 
Cluster 1 includes the younger respondents, with lesser economic means, mostly comprised of students displaying a greater and longer contact with the city of Coimbra; on the other hand, cluster 2 includes older, wealthier respondents who travelled for the first time to Coimbra, their trip being the first contact with the city and its history. Cluster 1 includes many nationals; in cluster 2 there is a high majority of foreigners.

As mentioned above, on the one hand, tourists in cluster 2 are more likely to value and engage in cultural activities that relate to the places visited; they are interested in learning and appreciate their experiences, leading them to feel greater satisfaction and loyalty. On the other hand, possibly due to their longer and most diverse life experiences, they tend not to see great economic benefits for the region simply because UNESCO classifies it as a WHS, in opposing stance with cluster 1 respondents.

McKercher \& du Cros (2003: 56) found out that of the many shades of cultural tourists, "the coveted purposeful cultural tourist is the exception rather than the norm, representing only a small minority of all people who participate in cultural tourism". The majority want to be entertained and don't look for deep learning experiences. This research doesn't confirm this theory as it demonstrates a greater maturity of cultural tourism, where a relevant importance is attributed to WHS classification by the UNESCO, as a motivational element to the increase of tourist demand and in situ activities. It is, therefore, established by this research that for visitors, mostly foreigners belonging to cluster 2 , it is important to interact and participate in cultural tourist experiences, leading them to the manifestation of a higher degree of satisfaction.

\section{1) IMPLICATIONS FOR MANAGERS}

To know the great diversity of the cultural tourism market and the potential size of segments and niches determines the types of cultural tourism products that are more suited to each segment. Consequently, special efforts should be encouraged to promote the cultural activities offered within the scope of the classification of places and monuments in the city of Coimbra. The promotion of initiatives should seek to involve and invite the participation of tourists so that they can learn about and deepen their learning about the places and their history. Bearing in mind the distinction between the characteristics of visitors' profiles, guided tours, the use of targeted 
technology tools, such as digital maps, and the offering of differentiated creative tourism products are examples of what can be done in order to encourage the participation of tourists.

The increase in visitor numbers demonstrates that the UNESCO seal is a powerful motivation factor in attracting tourists. Moreover, the results also show that tourists value participatory activities (theatre, music, dance, exhibitions, etc.) and other cultural activities, such as guided tour visits that enhance personal knowledge and valorize heritage, that can be participated in the premises, as well as broadcast or streamed in view of the pandemic situation. The current Covid-19 pandemic and all that evolved from it, at the economic, social and political levels, has further increased the use of innovation and technologies in tourism. Promotion of the UNESCO WHS through the utilization of digital technologies would provide potential tourists prior knowledge about the UNESCO site, aiming to keep the desire to travel alive to the destination.

Results reveal that there is a group of cultural tourists (cluster 2) for whom the WHS status is the main motivation for the trip, who value and prefer to engage in cultural activities that relate to the places visited; they are interested in learning and appreciate their experiences, leading them to feel greater satisfaction and loyalty. This is also the cluster composed of foreign visitors, with more money, but despite all that they are the ones with very short stays in the city, up to two days. This information can be very important for decision-making organizations and tour operators to ask themselves the reasons behind this behavior. Probably, these visitors lack the necessary previous information about all the activities that are offered in the sites at the time when they are planning their trip. Thus, a stronger performance on the part of organizations and entities in publicizing the cultural offer existing in the city and, more specifically, in the places that are heritage of humanity, would lead these tourists to plan a longer stay in the city.

In conclusion, this segmentation work, based on very relevant determinants of behavior, may bring advantages for those responsible for planning cultural tourist destinations and for tour operators and managers as it highlights the existence of clusters of identifiable characteristics, which differ not only in sociodemographic aspects, but also in attitudinal stance and preferences. With this knowledge, new tools can be provided by those responsible for planning and tourism managers, directing their attention to increasing the attractiveness of cultural destinations through the 
creation and design of new products and marketing strategies directed to each of the identified segments.

\section{2) LIMITATIONS OF THIS STUDY AND SUGGESTIONS FOR FUTURE RESEARCH}

Despite the practical contributions of the present study, some limitations are recognized. This research was carried out only in a city in Central Portugal and focused on some strategic points in the city, mainly through a quantitative approach. Even considering the cultural relevance of the city, namely as a UNESCO WHS, a similar analysis could also be implemented in other cities in the country as well as in foreign cities. A similar analysis in other cities in the country also classified by UNESCO would be of high interest for a combined analysis of segments based on the behavior of tourists. It should be noted that the present work is based on a matrix of quantitative approach, so qualitative approaches to the themes explored in the research can be useful for understanding the reasons, activities and behavior of tourists, providing relevant information for anticipating the future cultural tourism market preferences and expectations.

\section{References}

Alazaizeh, M.; Halo, J.; Backman, S.; Norman, W.; Vogel, M. Value orientations and heritage tourism management at Petra Archaelogical Park, Jordan. Tourism Management, Vol. 57, No December, 2016, pp. 149-158.

Barbieri; C.; Mahoney, E. Cultural tourism behaviour and preferences among the liveperforming arts audience: An application of the univorous-omnivorous framework. International Journal of Tourism Research, Vol. 12, No 5, 2010, pp. 481-496.

Bendix, R. Heritage between economy and politics. An assessment from the perspective of cultural anthropology. In Smith, L.; Akagawa, N. (Eds.). Intangible Heritage. Abingdon: Routledge, 2009, pp. 253-269. 
Bourdeau, L.; Gravari-Barbas, M.; Robinson, M. (Eds.). World Heritage, Tourism and Identity. Inscription and Co-production. London: Routledge, 2016.

Bryce, D.; Curran, R.; O'Gorman, K.; Taheri, B. Visitors' engagement and authenticity: Japanese heritage consumption. Tourism Management, Vol. 46, No February, 2015, pp. 571-581.

Carreira, V.; Azeredo, J.; González-Rodriguez, R.; Díaz-Fernández, C. The Role of Tourism Education in Overtourism and Destination Management. In Sharma, A.; Hassan, A. (Eds.). Over-tourism as Destination Risk: Impacts and Solutions. Bingley: Emerald Publishing, 2021, pp. 35-48.

Chen, G.; Huang, S. Towards an improved typology approach to segmenting cultural tourists. International Journal of Tourism Research, Vol. 20, No. 2, 2018, pp. 247-255.

Chhabra, D.; Healy, R.; Sills, E. Staged authenticity and heritage tourism. Annals of Tourism Research. Vol. 30, No 3, 2003, pp. 702-719.

Chi, C.; Qu, H. Examining the structural relationships of destination image, tourist satisfaction and destination loyalty: An integrated approach. Tourism Management, Vol. 29, No 4, 2008, pp. 624-636.

Cleere, H. The Impact of World Heritage Listing. In ICOMOS 17th General Assembly, 2011-11-27 / 2011-12-02, Paris, France. [Conference or Workshop Item]. Retrieved from http://openarchive.icomos.org/id/eprint/1209/1/III-1-Article3 Cleere.pdf [accessed 19 December 2020]. 
Cutler, Q.S.; Carmichael, B. The dimensions of the tourist experience. In Morgan, M.; Lugosi, P.; Ritchie, B. (Eds.). The Tourism and Leisure Experience: Consumer and Managerial Perspectives. Bristol: Channel View Publications, 2010, pp. 3-26.

du Cros, H.; McKercher, B. Cultural Tourism. London: Routledge 2014.

Evans, G. Living in a world heritage city: stakeholders in the dialectic of the universal and particular. International Journal of Heritage Studies, Vol. 8, No 2, 2002, pp. 117135.

Frey, B.S.; Pamini, P.; Steiner, L. Explaining the World Heritage List: an empirical study. International Review of Economics, 60, 2013, pp.1-19.

Heitman, S. Tourist Behaviour and Tourism Motivation. In Robinson, P; Heitman, S.; Dieke, P. (Eds.). Research Themes for Tourism. Wallingford: CABI, 2011, pp. 31-44.

Iso-Ahola, S.E. Toward a Social Psychology of Theory of Tourism Motivation - A Rejoinder. Annals of Tourism Research, Vol. 9, No 2, 1982, pp. 256-262.

Jimura, T. World Heritage Sites. Tourism, Local Communities and Conservation Activities. Wallingford: CABI, 2019.

Jimura, T. The impact of world heritage site designation on local communities - A case study of Ogimachi, Shirakawa-mura, Japan. Tourism Management, Vol. 32, No 2, 2011, pp. 288-296.

Kastenholz, E. Management of demand as a tool in sustainable tourist destination development. Journal of Sustainable Tourism. Vol. 12, No 5, 2004, pp. 388-408. 
Kastenholz, E.; Carneiro, M.J.; Eusébio, C. The impact of socio-demographics on tourist behavior - analyzing segments of cultural tourist visiting Coimbra. Paper presented at the International Conference on Advances in Tourism Economics. University of Évora (Portugal), 2005. Retrieved from https://d1watxts1xzle7.cloudfront.net/46956679/Aveiro.pdf [accessed 24 October 2020].

Kim, S. World Heritage Site Designation Impacts on a Historic Village: A case Study on Residents' Perceptions of Hahoe Village (Korea). Sustainability, Vol. 8, No. 3, 2016, pp. 258-.

Kolar, T.; Zabkar, V. A consumer-based model of authenticity: An oxymoron or the foundation of cultural heritage marketing? Tourism Management, 31, 2010, pp. 652664.

Landorf, C. Managing for sustainable tourism: a review of six cultural World Heritage Sites. Journal of Sustainable Tourism, Vol. 17, No 1, 2009, pp. 53-70.

Lawson, R. Demographic Segmentation. In Witt, S.; Moutinho, L. (Eds.).Tourism Marketing and Management Handbook. London: Prentice Hall, 1995, pp. 306-315.

Loker, L.E.; Perdue, R.R. A benefit-based segmentation of a nonresident summer travel market. Journal of Travel Research. Vol. 31, No 1, 1992, pp. 30-35. Retrieved from

https://citeseerx.ist.psu.edu/viewdoc/download?doi=10.1.1.1021.5876\&rep=rep1\&typ $\underline{\mathrm{e}=\mathrm{pdf}}$ [accessed 12 November 2020]. 
López-Guzmán, T.; Pérez-Gálvez, J.C.; Muñoz-Fernández, G.A.; Medina-Viruel, M.J. Cultural identity in WHS tourist destinations: the case of Córdoba (Spain). International Journal of Culture, Tourism and Hospitality Research. Vol. 12, No 4, 2018, pp. 427439.

McKercher, B. Towards a Classification of Cultural Tourists. International Journal of Tourism Research, Vol. 4, No 1, 2002, pp. 29-38.

McKercher, B.; du Cros, H. Testing a Cultural Tourism Typology. International Journal of Tourism Research, Vol. 5, No 1, 2003, pp. 45-58.

McKercher, B.; du Cros, H. Cultural Tourism: The Partnership between Tourism and Cultural Heritage Management. Binghampton: Haworth Press, 2002.

McKercher, B; Ho, P.; du Cros, H. Relationship between tourism and cultural heritage management. Evidence from Hong Kong. Tourism Management, Vol. 26, No 4, 2005, pp. 539-548.

Menezes, L. Interview with the newspaper As Beiras (27-09-2017).

Meskell, L. States of Conservation: Protection, Politics, and Pacting within UNESCO's World Heritage Committee. Anthropological Quarterly, Vol. 87, No 1, 2014, pp. 217244. Retrieved from http://www.jstor.org/stable/43652726 [accessed 11 April 2021].

Meskell, L. The rush to inscribe: Reflections on the $35^{\text {th }}$ Session of the World Heritage Committee, UNESCO, Paris. Journal of Field Archaeology, Vol. 37, No. 2, 2012, pp. 145-151. 
Nguyen, T.H.H.; Cheung, C. The classification of heritage visitors: A case of Hue City, Vietnam. Journal of Heritage Tourism, Vol. 9, No 1, 2014, pp. 35-50.

Novelli, M.; Benson, A. Niche tourism. A way forward to sustainability? In Novelli, M. (Ed.). Niche Tourism. Contemporary Issues, Trends and Cases. Oxford: Elsevier, 2005, pp. 247-250.

Poria, Y.; Reichel, A.; Cohen, R. Tourists perceptions of World Heritage Site and its designation. Tourism Management, Vol. 35, No April, 2013, pp. 272-274.

Poria, Y.; Reichel, A.; Biran, A. Heritage site management: Motivations and expectations. Annals of Tourism Research, Vol. 33, No 1, 2006, pp. 162-178.

Poria Y.; Butler, R.; Airey, D. Clarifying heritage tourism. Annals of Tourism Research, Vol. 28, No 4, 2001, pp. 1047-1049.

Quinteiro, S.; Carreira, V.; Gonçalves, A. Coimbra as a literary tourism destination the places of literature. The International Journal of Culture, Tourism, and Hospitality Research. Vol. 14, No 3, 2020, pp. 361-372.

Ramires, A.; Brandão, F.; Sousa, A.C. (2018). Motivation-based cluster analysis of international tourists visiting a World Heritage City: The case of Porto, Portugal. Journal of Destination Marketing \& Management, Vol. 8, No June, 2018, pp. 49-60.

Ribeiro, J.C.; Vareiro, L.; Santos, J.F. Tourists' perceptions of world heritage destinations: The case of Guimarães (Portugal). Tourism and Hospitality Research, Vol. 14, No 4, 2014, pp. 206-218. 
Richards, G. Cultural tourism: A review of recent research and trends. Journal of Hospitality and Tourism Management, Vol. 36, No September, 2018, pp.12-21.

Richards, G. Creativity and tourism: The state of the art. Annals of Tourism Research, Vol. 38, No 4, 2011, pp. 1225-1253.

Richards, G. (Ed.). Cultural Tourism in Europe. Wallingford: CAB International, 1996.

Richards, G.; van der Ark, A. Dimensions of Cultural Consumption among Tourists: Multiple Correspondence Analysis. Tourism Management, Vol. 37, No August, 2013, pp. 71-76.

Richards, G.; Marques, L. Exploring Creative Tourism: Editors Introduction. Journal of Tourism Consumption and Practice. Vol. 4, No 2, 2012, pp. 1-12.

Richards, G.; Raymond, C. Creative tourism. ATLAS News, No 23, 2000, pp. 16-20. Retrieved from

https://www.academia.edu/1785786/Creative Tourism Richards and Raymond 20 $\underline{00}$ [accessed 10 January 2021].

Richards, G.; Wilson, J. (Eds.). Tourism, Creativity and Development. London/New York: Routledge, 2007.

Santa-Cruz, F.G.; López-Guzmán, T. Culture, Tourism and World Heritage Sites. Tourism Management Perspectives, Vol. 24, 2017, pp. 111-116. 
Seraphin, H.; Sheeran, P.; Pilato, M. Over-tourism and the fall of Venice as a destination. Journal of Destination Marketing \& Management, Vol. 9, No September, 2018, pp. 374-376.

Silva, S.; Carvalho, P. On the UNESCO World Heritage route. Characteristics and behaviours of visitors to the University of Coimbra's Botanical Garden. In Cravidão, F.; Santos, N.;Moreira, C.; Ferreira, R.; Nossa, P.; Silveira, L. (Eds.). Proceedings of the $5^{\text {th }}$ UNESCO UNITWIN Conference - Local Identity and Tourism Management on World Heritage Sites, 18-22 Abril. Coimbra: Universidade de Coimbra, 2017, pp. 3956.

Smith, M.A Critical Evaluation of the Global Accolade: the significance of World Heritage Site status for Maritime Greenwich. International Journal of Heritage Studies, Vol. 8, No 2, 2002, pp. 137-151.

Smith, S.L.J. Practical Tourism Research. Wallingford: CABI, 2017.

Taheri, B.; Jafari, A.; O'Gorman, K. Keeping your audience: Presenting a visitor engagement scale. Tourism Management, Vol. 42, No June, 2014, pp. 321-329.

Tiberghien, G.; Bremner, H.; Milnec, S. Performance and visitors' perception of authenticity in ecocultural tourism. Tourism Geographies, Vol. 19, No 2, 2017, pp. 287300.

Timothy, D.J. Cultural Heritage and Tourism. An Introduction. Bristol: Channel View Publications, 2011.

Timothy D.J. Tourism and the personal heritage experience. Annals of Tourism Research. Vol. 24, No 3, 1997, pp. 751-754. 
Timothy, D.J.; Boyd, S. Heritage Tourism. Harlow: Pearson Education Limited, 2003.

UNWTO. Tourism and Culture Synergies. Madrid: UNWTO, 2018.

UNWTO. Definitions. Committee on Tourism and Competitiveness, 2017. Retrieved from http://cf.cdn.unwto.org/sites/all/files/docpdf/ctcdefinitionsenweb.pdf [accessed 10 March 2020].

Uriely, N. The Tourist Experience: Conceptual Developments. Annals of Tourism Research. Vol. 32, No. 1, 2005, pp. 199-216.

Veal, A.J. Research Methods for Leisure and Tourism. London: Pearson, 2017.

WTO. The State's Role in Protecting and Promoting Culture as a Factor of Tourism Development. Madrid: WTO, 1985.

Yang, C.-H.; Lin, H.-L.; Han, C.-C. Analysis of tourist arrivals in China: The Role of World Heritage Sites. Tourism Management, Vol. 31, No 6, 2010, pp. 827-837.

Zhu, Y. Performing Heritage: Rethinking Authenticity in Tourism. Annals of Tourism Research. Vol. 39, No 3, 2012, pp. 1495-1513.

Article info: Received 15/04/2021. Accepted 02/06/2021. Refereed anonymously. 